Proceeding Paper

\title{
Synthesis of Nanosized Powders for Lead-Acid Battery Pastes by Recycling of Used Batteries ${ }^{\dagger}$
}

\author{
Mariela T. Dimitrova * and Sasho V. Vassilev
}

Citation: Dimitrova, M.T.; Vassilev, S.V. Synthesis of Nanosized Powders for Lead-Acid Battery Pastes by Recycling of Used Batteries. Mater. Proc. 2021, 4, 78. https://doi.org/10.3390/ IOCN2020-07853

Academic Editors: Ana María Díez-Pascual, Antonio Di Bartolomeo and Guanying Chen

Published: 11 November 2020

Publisher's Note: MDPI stays neutral with regard to jurisdictional claims in published maps and institutional affiliations.

Copyright: (c) 2020 by the authors. Licensee MDPI, Basel, Switzerland. This article is an open access article distributed under the terms and conditions of the Creative Commons Attribution (CC BY) license (http://creativecommons.org/licenses /by/4.0/).
Institute of Electrochemistry and Energy Systems, Bulgarian Academy of Sciences,

Akad. G. Bonchev str, bl. 10, 1113, Sofia, Bulgaria; sasho.vassilev@iees.bas.bg

* Correspondence: mariela.dimitrova@iees.bas.bg

† Presented at the 2nd International Online-Conference on Nanomaterials, 15-30 November 2020; Available online: https://iocn2020.sciforum.net/.

\begin{abstract}
In the present work we have investigated the oxysulfate fraction of spent lead-acid battery pastes in search of an optimal method for its recycling. For this purpose, desulfurization and leaching were performed in one step by simultaneously adding aqueous solutions of sodium citrate and citric acid at varying temperatures $\left(25-100{ }^{\circ} \mathrm{C}\right)$ and heat treatment times $(1-2 \mathrm{~h})$ in order to obtain a lead citrate precursor for direct application in the production of lead oxide powder. Two types of lead citrate were obtained: $\mathrm{Pb}\left(\mathrm{C}_{6} \mathrm{H}_{6} \mathrm{O}_{7}\right) \cdot \mathrm{H}_{2} \mathrm{O}$ and $\mathrm{Pb}_{3}\left(\mathrm{C}_{6} \mathrm{H}_{5} \mathrm{O}_{7}\right)_{2} \cdot 3 \mathrm{H}_{2} \mathrm{O}$. After calcination at low temperature $\left(300^{\circ} \mathrm{C}\right)$, these precursors formed a nanosized lead oxide powder. X-ray diffraction analysis $(\mathrm{XRD})$ was performed at each stage of the study to monitor the changes in phase composition and crystallite size of the synthesized powder. Morphological features were investigated by scanning electron microscopy (SEM). An additional differential thermal analysis (DTA) was performed to determine the type of the obtained lead citrate. Finely dispersed lead oxide powders were formed. The measured crystallite sizes of the two main phases were 30-50 nm for $\beta-\mathrm{PbO}_{(111)}$ and $40-60 \mathrm{~nm}$ for $\mathrm{Pb}_{(111)}$.
\end{abstract}

Keywords: spent lead-acid batteries; lead citrate; desulfurization; leaching; recycling

\section{Introduction}

Recently, with the entry of the new millennium, for the production of lead-acid batteries, the use of secondary refined lead reached $60-66 \%$ of the total lead [1]. Recycling used lead batteries saves natural resources, consumes less energy to produce lead, and significantly avoids air and water pollution. The complex composition of the spent lead paste creates many difficulties in its processing into lead through a process of energy-intensive decomposition and desulfurization [2,3]. Several techniques have been developed to save energy by creating industrial facilities in order to create a method for saving energy and controlling the emissions of total solid particles in lead production $[1,4]$. The hydrometallurgical methods of battery recycling are more widely used $[5,6]$. They involve the oxidation of lead waste by treatment with $\mathrm{Na}_{2} \mathrm{CO}_{3},\left(\mathrm{NH}_{4}\right)_{2} \mathrm{CO}_{3}$ or $\mathrm{NaOH}$. The received lead carbonate, hydroxide or hydroxycarbonate is subjected to pyrometallurgical treatment at lower temperatures $\left(400-650{ }^{\circ} \mathrm{C}\right)$ compared to pyrometallurgical methods $\left(900-1400{ }^{\circ} \mathrm{C}\right)$ [7-11]. In recent years, research has been based on the need to develop an efficient, low-cost environmental technology for recycling waste lead paste. Experiments to extract $\mathrm{Pb}$ from used lead paste by treatment with aqueous citric acid solution lead to the generation of a lead citrate precursor, which can easily be converted to $\mathrm{PbO}$ for direct production of lead pastes for batteries. Controlling the calcination process may lead to variations in the microstructure and the formation of micro- to nanosized powders - a new perspective in the development of lead-acid battery technology $[12,13]$. 
The purpose of our research is to find an optimal method for the recycling of used lead-acid batteries in order to recover lead from positive (PAM) and negative (NAM) active masses and obtain lead oxide powders for direct application in the formation of lead-acid pastes.

\section{Materials and Methods}

Desulfurization and leaching were performed in one step by simultaneously adding aqueous solutions of $\mathrm{C}_{6} \mathrm{H}_{5} \mathrm{Na}_{3} \mathrm{O}_{7} .2 \mathrm{H}_{2} \mathrm{O}(0.5 \mathrm{~mol} / \mathrm{L})$ and $\mathrm{C}_{6} \mathrm{H}_{8} \mathrm{O}_{7}(0.8 \mathrm{~mol} / \mathrm{L}, 1 \mathrm{~mol} / \mathrm{L})$ at varying temperatures $\left(25-100{ }^{\circ} \mathrm{C}\right)$ and heat treatment times $(1-2 \mathrm{~h})$. The ratio $\mathrm{PbSO}_{4} / \mathrm{C}_{6} \mathrm{H}_{5} \mathrm{Na}_{3} \mathrm{O}_{7} .2 \mathrm{H}_{2} \mathrm{O} / \mathrm{C}_{6} \mathrm{H}_{8} \mathrm{O}_{7}$ was $1: 2.5: 2.5$. Hydrogen peroxide was added to the samples of the positive active masses as a reducing agent for the conversion of $\mathrm{Pb}(\mathrm{IV})$ to $\mathrm{Pb}$ (II) at the sample/acid solution/peroxide ratio of 1:1.5:2. The calcination was carried out by heating at $300{ }^{\circ} \mathrm{C}$ for $1 \mathrm{~h}$. Initially, the experiments were conducted with chemical purity substances $\left(\mathrm{PbO}_{2}, \mathrm{~Pb}\left(\mathrm{NO}_{3}\right)_{2}\right.$ and $\left.\mathrm{PbSO}_{4}\right)$ and lead oxide powder $(85.7 \% \mathrm{PbO} / 14.3 \% \mathrm{~Pb})$ for determining the appropriate conditions to prevent the lead losses during its recovery. The spent positive and negative active masses had the following chemical compositions: NAM: 68.9\% $\mathrm{PbSO}_{4}$, 24.56\% Pb, 2.98\% PbO; PAM: 33.08\% $\mathrm{PbSO}_{4}, 66.37 \% \mathrm{PbO}_{2}$.

The phase composition was determined by XRD, using a Philips PW 1030 X-ray diffractometer with a Bragg-Brentano $\theta-2 \theta$ geometry, $\mathrm{CuK} \alpha$ radiation $(30 \mathrm{kV}, 20 \mathrm{~mA})$ with wavelength $\lambda=1.5406 \AA$ and scintillation detector. A scanning electron microscope (JEOL JEM-200CX) was used for morphology observation of the samples. The images were taken in secondary electrons mode (SE) at accelerating voltage of $80 \mathrm{keV}$. DTA/TG analysis was performed by Labsys Evo 1600 Setaram.

\section{Results and Discussion}

During the experiment, it was found that the final result of desulfurization and leaching of spent active masses of lead batteries is the formation of different phases. These results provoked us to conduct additional research on the preparation of lead salts as a product of recycling. For this purpose, we used chemically pure lead citrate

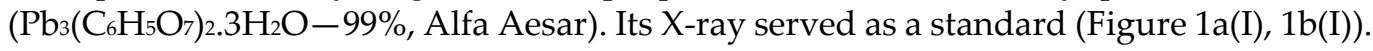
Figure 1a shows the diffractograms of lead citrate obtained from chemically pure substances $\left(\mathrm{PbO}_{2}, \mathrm{~Pb}\left(\mathrm{NO}_{3}\right)_{2}, \mathrm{PbSO}_{4}\right)$ under the following conditions: $2 \mathrm{~h}$ magnetic stirring, $1 \mathrm{~h}$ heating at $40{ }^{\circ} \mathrm{C}, 0.8 \mathrm{~mol} / \mathrm{L}$ citric acid solution, and $0.5 \mathrm{~mol} / \mathrm{L}$ sodium citrate solution + $\mathrm{H}_{2} \mathrm{O}_{2}$ for $\mathrm{Pb}(\mathrm{IV})$. The results confirm the conclusions made so far in the literature on the type of lead citrate $[12,14]$. Therefore, the appearance of a high-intensity peak at $\sim 7.8^{\circ} 2 \theta$ may be associated with the production of $\mathrm{Pb}\left(\mathrm{C}_{6} \mathrm{H}_{6} \mathrm{O}_{7}\right) \cdot \mathrm{H}_{2} \mathrm{O}$. As can be seen, in the case of starting from lead oxide powder, $\mathrm{PbO}_{2}$ and $\mathrm{Pb}\left(\mathrm{NO}_{3}\right)_{2}$, lead citrate monohydrate was formed (Figure 1a(II, III, IV)). Their diffractograms did not correspond to the standard. When lead sulfate was used as raw material after desulfurization and leaching, it did not dissolve completely, and its peaks are registered in the diffractogram, as well as those of two types of lead citrate (Figure $1 \mathrm{a}(\mathrm{V})$ ). Figure $1 \mathrm{~b}$ presents the results of XRD analysis of selected samples of positive (PAM) and negative (NAM) active mass after recycling, as well as lead citrate obtained by following the methodology of patent SU 1159958, which reports the formation of lead citrate from lead nitrate and citric acid [15]. The results are somewhat consistent with those obtained using chemically pure products. In the case of desulfurization and leaching of $\mathrm{PAM}$, in contrast to pure $\mathrm{PbO}_{2}, \mathrm{~Pb}_{3}\left(\mathrm{C}_{6} \mathrm{H}_{5} \mathrm{O}_{7}\right)_{2} .3 \mathrm{H}_{2} \mathrm{O}$ was formed while the X-ray pattern of NAM under one of the same sets of conditions (temperature and heat treatment time) shows the formation of lead monohydrate (Figure $1 \mathrm{~b}(\mathrm{II}, \mathrm{III}))$. A mixture of two citrates was observed in the diffraction pattern of the final synthesis product carried out according to the above patent (Figure $1 \mathrm{~b}(\mathrm{IV})$ ). 


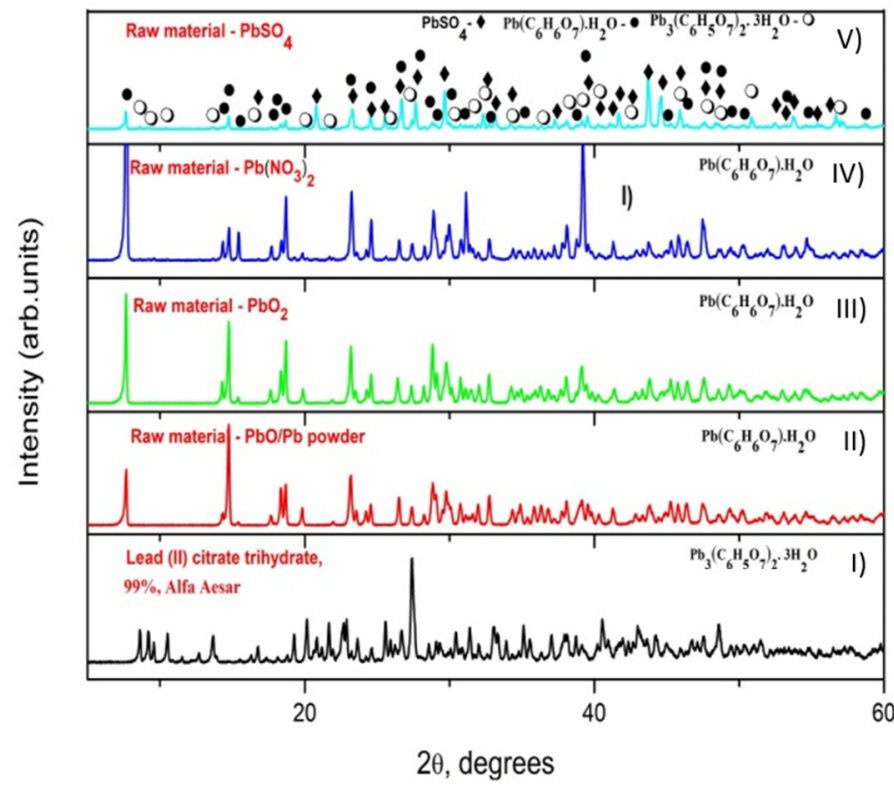

(a)

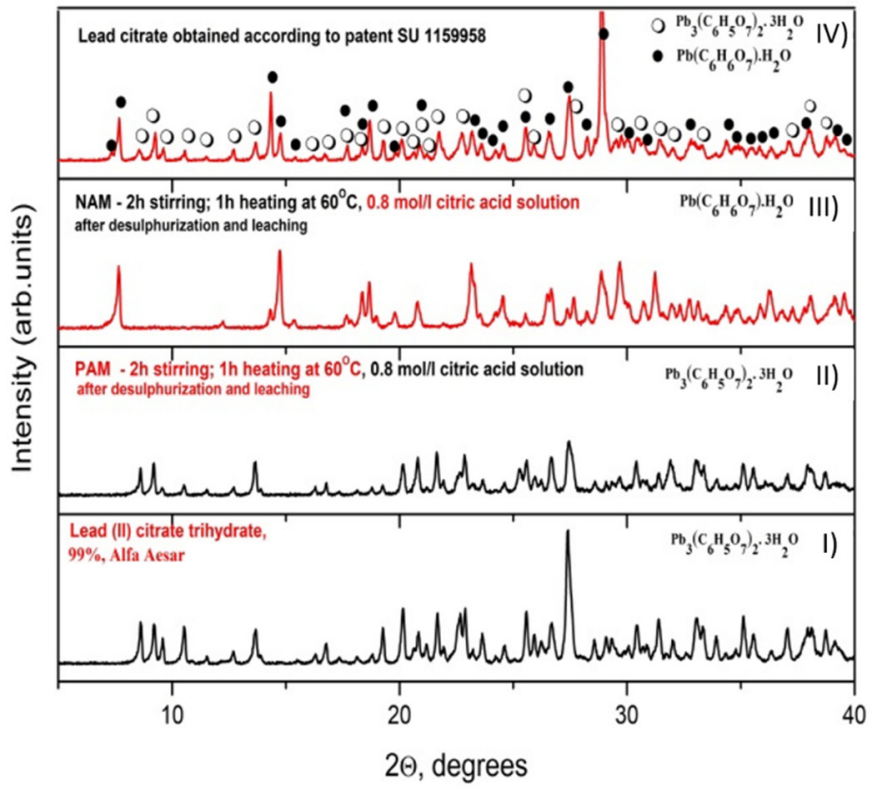

(b)

Figure 1. XRD diagrams of lead citrate synthesized from (a) chemically pure products and (b) spent active masses (PAM and NAM) of lead-acid batteries compared with chemically pure lead citrate trihydrate and lead citrate obtained under patent SU 1159958.

A negative active mass was treated to compare the results obtained using citric acid solutions with different concentrations. Lead citrate trihydrate was obtained when using a solution with a lower concentration $(0.8 \mathrm{~mol} / \mathrm{L})$, temperature $\left(40^{\circ} \mathrm{C}\right)$ and heat treatment time $(1 \mathrm{~h})$. After calcination, the XRD diagram shows that the main phase formed is $\beta-\mathrm{PbO}$ and a small amount of $\mathrm{Pb}$ (Figure $2 \mathrm{a}(\mathrm{I}, \mathrm{II})$ ), and the absence of a peak at $29.69^{\circ} 2 \theta$ proves that the desulfurization was complete. At a higher concentration $(1 \mathrm{~mol} / \mathrm{L})$ of the acid solution, the desulfurization was not complete, and residual lead sulfate was present in addition to lead citrate monohydrate. In the received lead oxide powder, the base phase is again $\beta-\mathrm{PbO}$ and a small amount of $\mathrm{Pb}$. In this case, $\alpha-\mathrm{PbO}$ was formed, along with oxide sulfates $\left(\mathrm{PbO}^{\mathrm{PbSO}} 4\right.$ and $4 \mathrm{PbO}^{\mathrm{PbSO}} 4$ ) in significant amounts (Figure 2a(III,IV)). 


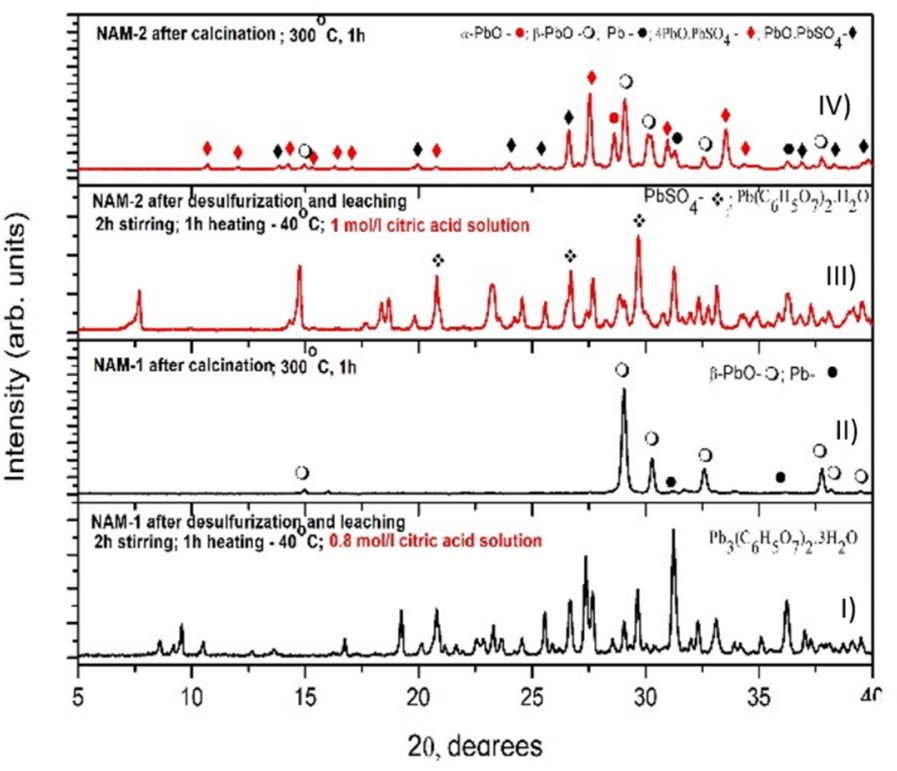

(a)

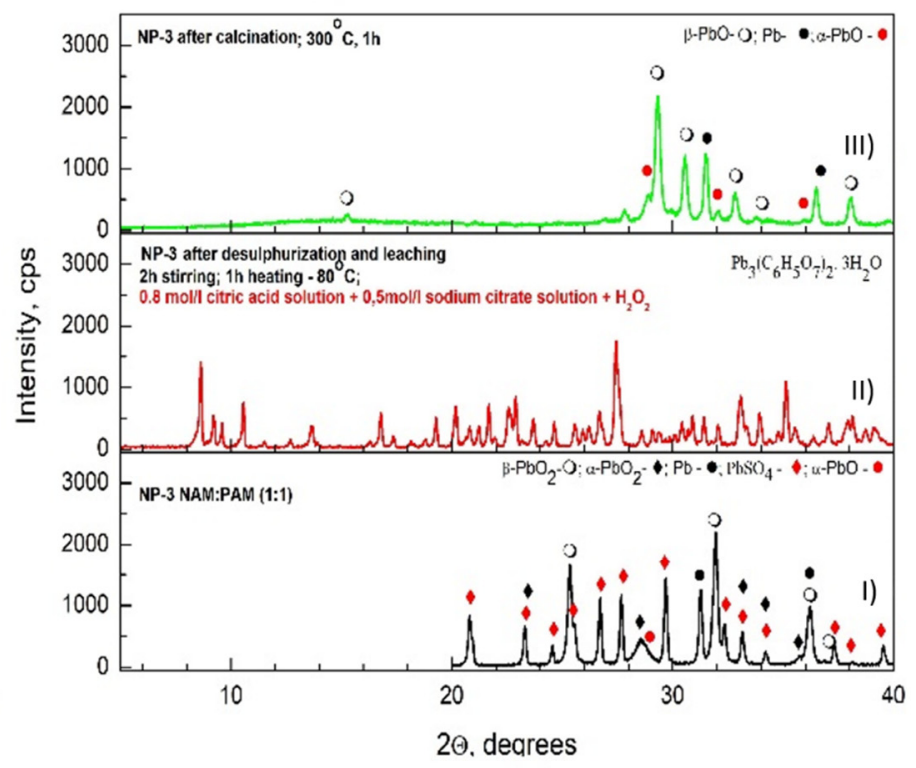

(b)

Figure 2. XRD diagrams: (a) Lead citrate synthesized from NAM (I, III) after desulfurization and leaching depending on the concentration of the citric acid solution and (II, IV) after calcination. (b) Lead citrate synthesized from a mixture of used positive and negative active mass (NP-3) (I) before recycling, (II) after desulfurization and leaching and (III) after calcination.

All reported results were recorded starting from pure chemicals, positive active mass, or negative active mass. They gave us the basic guidelines on how to conduct the experiment, approaching the real conditions of recycling lead-acid batteries. For this purpose, we mixed 1:1 RAM and NAM (sample NP-3) and applied a methodology established on the basis of the optimal conditions achieved so far. Figure $2 b$ shows the XRD diagrams of the mixed sample before and after desulfurization and leaching (Figure $2 \mathrm{~b}(\mathrm{I}, \mathrm{II}))$. The obtained lead citrate is $\mathrm{Pb}_{3}\left(\mathrm{C}_{6} \mathrm{H}_{5} \mathrm{O}_{7}\right)_{2} \cdot 3 \mathrm{H}_{2} \mathrm{O}$ without the presence of $\mathrm{PbO}_{2}$ and $\mathrm{PbSO}_{4}$. After calcination at $300^{\circ} \mathrm{C}$ for $1 \mathrm{~h}$, high-purity lead oxide powder was obtained for direct application in the formation of active masses for lead-acid batteries (Figure $2 b(\mathrm{III}))$.

The crystallite sizes $(t)$ were determined by Scherer's formula: $t=\kappa \lambda / B \cos \theta$, where $k$ is shape factor ( $\mathrm{k}=0.9$ for spherical crystals with cubic symmetry), $\lambda(\AA)$ is the wavelength, $\theta$ is the diffraction angle of the peak and B (rad) is the line broadening at the full width at half maximum (FWHM) values of the peaks. The measured crystallite sizes of the two main phases of obtained lead oxide powders after calcination of samples NAM-1 and $\mathrm{NP}-3$ were $\beta-\mathrm{PbO}_{(111)}-46 \mathrm{~nm}, \mathrm{~Pb}_{(111)}-57 \mathrm{~nm}$ and $\beta-\mathrm{PbO}_{(111)}-37 \mathrm{~nm}, \mathrm{~Pb}_{(111)}-49 \mathrm{~nm}$, respectively.

These results and the conclusions reached regarding the type of citrate can to some extent be confirmed by the DTA/TG analysis. Figure 3a presents the results of the DTA analysis of $\mathrm{Pb}_{3}\left(\mathrm{C}_{6} \mathrm{H}_{5} \mathrm{O}_{7}\right)_{2} .3 \mathrm{H}_{2} \mathrm{O}$ used as a reference in our studies. The endoeffect at $135.4^{\circ}$ C, as well as $4.27 \%$ weight loss, may be related to the dehydration of lead crystal hydrate. As can be seen for the citrate obtained by leaching PAM at approximately the same temperature $\left(138.8^{\circ} \mathrm{C}\right)$, an endoeffect was observed again, as well as one with less heat absorption at $165.6^{\circ} \mathrm{C}$, which at this stage is still difficult to explain (Figure 3b). In this case, in the XRD analysis, in addition to lead citrate, $\mathrm{PbO}_{2}$ and $\mathrm{PbSO}_{4}$ were registered in small quantities and additional transformations were obviously taking place, which is evidenced not only by the manifestation of the additional endoeffect but also by greater weight loss $(6.44 \%)$. The linear character of the curve of the lead citrate obtained from chemically pure $\mathrm{Pb}\left(\mathrm{NO}_{3}\right)_{2}$ shows that the anhydrous form of lead citrate is formed during 
its synthesis from chemically pure products, which on the other hand differs from the initial conclusion based on the data from the literature (Figure 3c).

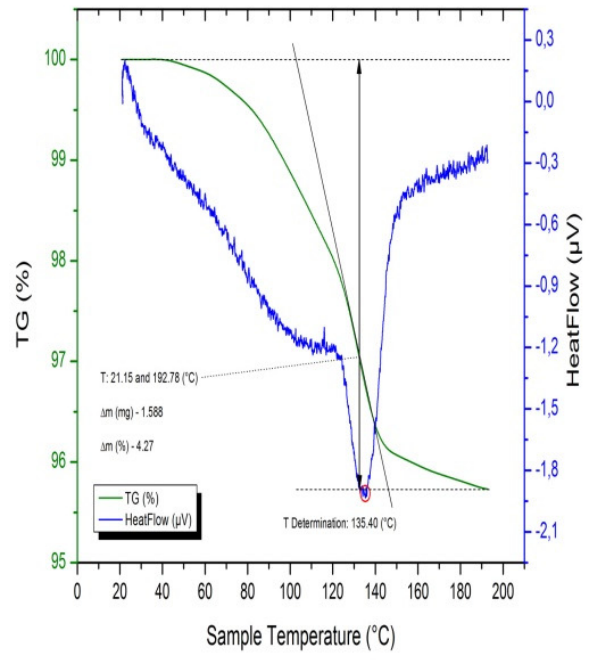

(a)

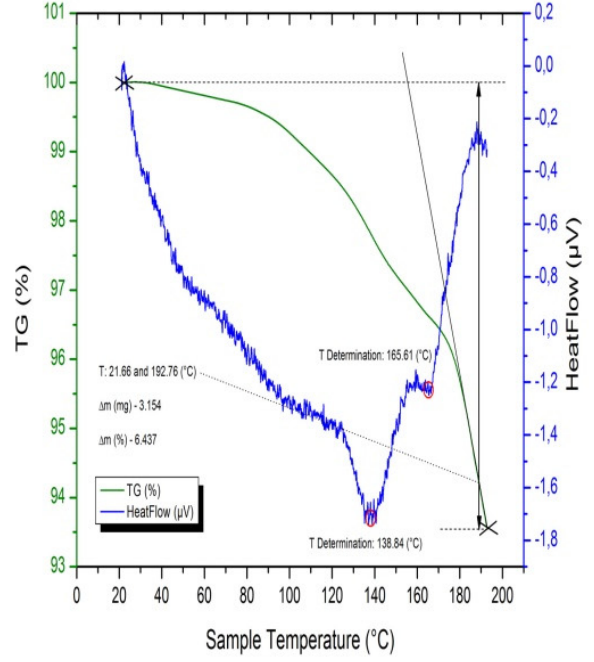

(b)

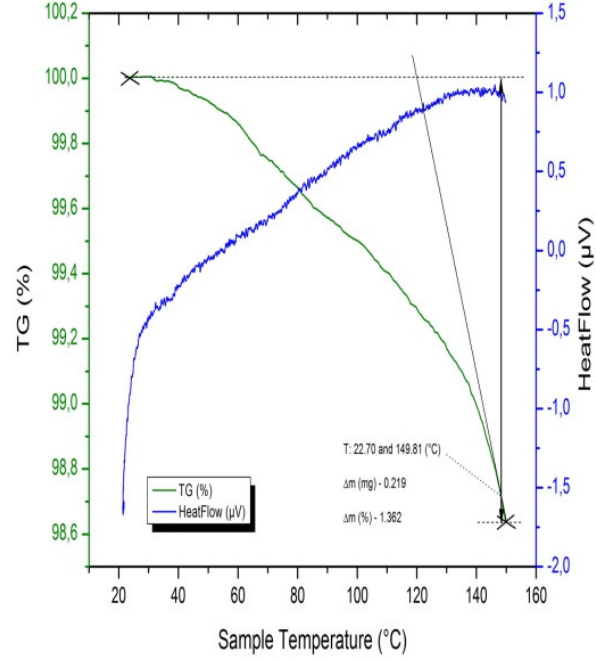

(c)

Figure 3. DTA/TG analysis of lead citrate: (a) $\mathrm{Pb}_{3}\left(\mathrm{C}_{6} \mathrm{H}_{5} \mathrm{O}_{7}\right)_{2} .3 \mathrm{H}_{2} \mathrm{O}$ (c.p.); (b) synthesized by PAM desulfurization and leaching; (c) synthesized from chemically pure $\mathrm{Pb}\left(\mathrm{NO}_{3}\right)_{2}$.

The conducted SEM analysis allowed us to determine the morphological features of the obtained lead citrate. The images show that the crystallization is complete. The synthesized $\mathrm{Pb}_{3}\left(\mathrm{C}_{6} \mathrm{H}_{5} \mathrm{O}_{7}\right)_{2} .3 \mathrm{H}_{2} \mathrm{O}$ crystals fused together by desulfurization and leaching of PAM to form druses (Figure 4a). In the synthesis of lead citrate from a mixture of NAM and PAM (NP-3), long prismatic crystals with a length of up to $50 \mu \mathrm{m}$ and a cross-section of $\sim 5 \mu \mathrm{m}$ were formed (Figure $4 \mathrm{~b}$ ). In the lead citrate obtained under patent SU 1159958, where we established by XRD the presence of both types of citrate, the crystals with different shapes fused together to form druses (Figure 4c).

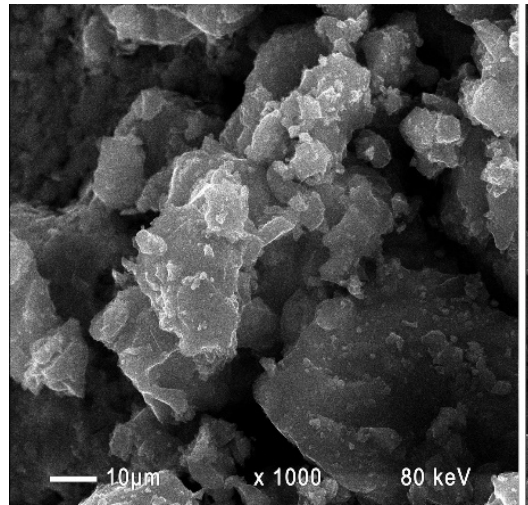

(a)

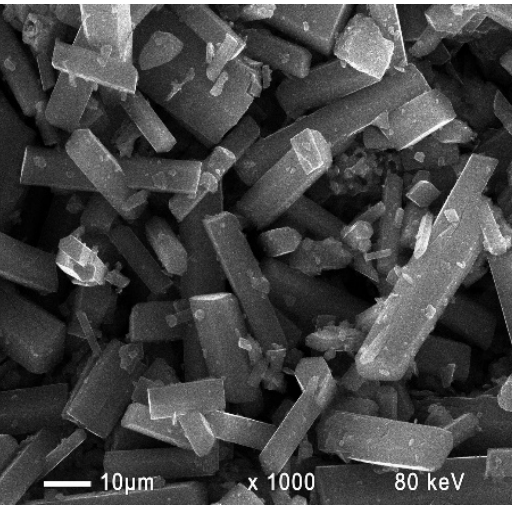

(b)

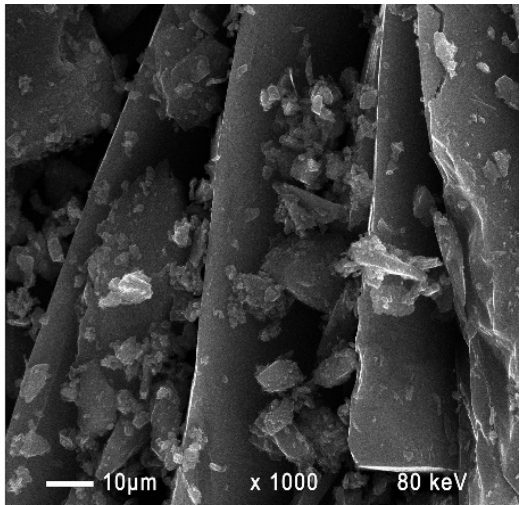

(c)

Figure 4. SEM images of lead citrate precursor: (a) synthesized by desulfurization and leaching of a used PAM; (b) synthesized by desulfurization and leaching of a mixture of used PAM and NAM; (c) synthesized under patent SU 1159958.

These results provide guidelines for further studies of lead citrate types, underscoring the importance of their crystallographic and morphological characteristics for the formation of lead oxide powders with optimal chemical composition and crystallite sizes for use in the production of lead-acid batteries with high storage capacity and long lifespan. 


\section{Conclusions}

- Two types of lead citrate precursors were obtained: $\mathrm{Pb}\left(\mathrm{C}_{6} \mathrm{H}_{6} \mathrm{O}_{7}\right) \cdot \mathrm{H}_{2} \mathrm{O}$ and $\left.\mathrm{Pb}_{3}\left(\mathrm{C}_{6} \mathrm{H}_{5} \mathrm{O}_{7}\right)_{2} .3 \mathrm{H}_{2} \mathrm{O}\right)$.

- The finely dispersed lead oxide powders obtained were suitable for use in the production of battery pastes by recycling.

- $\quad$ The measured crystallite sizes of the two main phases were $30-50 \mathrm{~nm}$ for $\beta-\mathrm{PbO}(111)$ and $40-60 \mathrm{~nm}$ for $\mathrm{Pb}(111)$.

Institutional Review Board Statement: Not applicable.

Informed Consent Statement: Not applicable.

Data Availability Statement: Our study did not report any data.

Acknowledgments: The authors thank Rositsa Andreeva for her technical assistance, Ognyan Dimitrov and Lyubomir Aleksandrov for SEM and DTA/TG analyses. This work was supported by the National Scientific Program NNP “Low Carbon Energy for Transport and Households-Eplus".

\section{References}

1. Zhang, W.; Yang, J.; Wu, X.; Hu, Y.; Yu, W.; Wang, J.; Dong, J.; Li, M.; Liang, S.; Hu, J.; et al. A critical review on secondary lead recycling technology and its prospect. Renew. Sust. Energ. Rev. 2016, 61, 108-122.

2. Chen, T.T.; Dutrizac, J.E. The mineralogical characterization of lead acid battery paste. Hydrometallurgy 1996, 40, $223-245$.

3. Ferracin, L.C.; Chácon-Sanhueza, E.C.; Davoglio, R.A.; Rocha, L.O.; Caffeu, D.J.; Fontanetti, A.R.; Rocha-Filho, R.C.; Biaggio, S.R.; Bocchi, N. Lead recovery from a typical Brazilian sludge of exhausted lead-acid batteries using an electrohydrometallurgical process. Hydrometallurgy 2002, 65, 137-144.

4. Abdel Basir, S.M.; Rabah, M.A. Hydrometallurgical recovery of metal values from brass melting slag. Hydrometallurgy 1999, $53,31-44$.

5. Rabah, M.A.; Barakat, M.A. Energy saving and pollution control for short rotary furnace in secondary lead smelter. Renew. Energy 2001, 23, 561-577.

6. Vaysgant, Z.; Morachevsky, A.; Demidov, A.; Klebanov, E. A low-temperature technique for recycling lead/acid battery scrap without wastes and with improved environmental control. J. Power. Sources 1995, 53, 303-306.

7. Lyakov, N.; Tsaneva, M.; Haralampiev, G.; Girdzhev, G. Research on desufurization of spent lead paste, In Yearbook VHTI; XXXI; Publisher: Ecole Superieure de Chimie Technologique, Sofia, Bulgaria, 1992; Volume 3, pp. 36-45. (In Bulgarian)

8. Prengaman, R.D.; McDonald, H. Method of Recovering Lead Values from Battery Sludge. U.S. Patent 4,229,271, 21 October 1980.

9. Prengaman, R.D.; McDonald, H.B. Process for Reducing Lead Peroxide Formation during Lead Electrowinning. U.S. Patent 4,230,545, 28 October 1980.

10. Prengaman, R.D. Recovering lead from batteries. JOM 1995, 47, 31-33.

11. Prengaman, R.D.; McDonald, H. Stable Lead Dioxide Anode and Method for Production. U.S. Patent 4,236,978, 2 December 1980.

12. Sonmez, M.S.; Kumar, R.V. Leaching of waste battery paste components. Part 1: Lead citrate synthesis from $\mathrm{PbO}$ and $\mathrm{PbO}$. Hydrometallurgy 2009, 95, 53-60.

13. Sonmez, M.S.; Kumar, R.V. Leaching of waste battery paste components. Part 2: Leaching and desulphurisation of $\mathrm{PbSO}_{4}$ by citric acid and sodium citrate solution. Hydrometallurgy 2009, 95, 82-86.

14. Kourgiantakis, M.; Matzapetakis, M.; Raptopoulou, C.P.; Terzis, A.; Salifoglou, A. Lead-citrate chemistry synthesis, spectroscopic and structural studies of a novellead(II)-citrate aqueous complex. Inorg. Chim. Act. 2000, 297, $134-138$.

15. Shklover, L.P.; Chicherina, G.P.; Serebrennikova, G.M.; Krasilshtik, V.Z. Method of Obtaining Metallic Lead. SU 1159958 A, 6 July 1985. (In Russian) 